\title{
The Influence of Head Master Leadership, Work Climate and Work Motivation Toward the Teachers Performance at SMA Negeri Binjai
}

\author{
Hendra, Tiur Siburian, Yasaratodo Wau \\ Learning Development Research History Education, magister of Administration Education, \\ State University of Medan, Medan, Indonesia \\ Corresponding author: hendrasihitangmpd@gmail.com
}

\begin{abstract}
The goal of the research is to describe and to know: (1) the influence of Head master leadership to work motvation; (2) the influence of Work climate to discipline of work; (3) the influence of Head master leadership to the teacher performance; (4) the influence of Work climate to teacher performance; and (5) the influence of work motvation to the teacher performance at SMA Negeri Binjai. This research method is quantitative methods. The model used is a path analysis with analysis techniques and inferensial. The population in this study is all teachers at high school teacher in the town of Binjai totalling 501 teachers. The research sample is determined by using the Nomogram Harry King to obtain a sample of 198 teachers. The research instrument for data collection was a questionaire. The results of this study found: (1) there is a direct and significant influence of Head master leadership to work motvation with the path coefficient $\rho_{31}=0,298$, (2) there is a direct and significant influence of Work climate to discipline of work with path coefficient $\rho_{32}=0,172$, (3) there is a direct and significant influence of Head master leadership to the teacher performance with path coefficient $\rho_{41}=\mathbf{0 , 1 5 8}$, (4) there is a direct and significant influence of Work climate to teacher performance with path correlation $\boldsymbol{\rho}_{42}=\mathbf{0 , 1 5 4}$, (5) there is a direct influence of work motvation to the teacher performance with path coefficient $\rho_{43}=\mathbf{0 , 2 9 0}$. Based on the results of the research above, it is suggested to the teachers to have high dedication in perform the profession as a teachers, teachers should be able to create a work climate with a harmonions work climate, The teachers should have high work motivation so that it is able to push a high teacher performance.
\end{abstract}

Keywords: Head master Leadership, Work Climate, Work Motivation, Teachers Performance

\section{INTRODUCTION}

The independence of a nation is determined by many factors, and human resources are the main factor. In the era of globalization that is most needed is human resources that have competitiveness, and education is the main capital that must be owned by everyone in order to have high competitiveness and ultimately bring many benefits to the wider community.
Schools as formal education have a very important role in forming superior and competitive human resources. Many improvements have been made in schools ranging from curriculum improvement, facilities, infrastructure, to improving the quality of teaching staff. All that is very necessary to be done in order to pay attention to the quality of education, but there are major factors that must be prioritized in making improvements, namely improving the quality of educators. As stated by [1]Tilaar that teachers or educators are the single factor that determines the quality of education.

[2]Mulyasa identifies at least nineteen roles of teachers in learning. The nineteenth role of teachers in learning is, teachers as educators, instructors, mentors, trainers, advisors, reformers (innovators), models and examples, personal, researchers, drivers of creativity, generating views, routine workers, campers, storytellers, actors, emancipator, evaluator, preservative, and as the culminator.

[3] Timpe suggests that the factors that influence work are (1) behavior, (2) attitude, (3) work actions, (4) subordinates, (5) leaders, (6) source constraints power, (7) economic conditions. [4]Furthermore As'ad in Sutiadi suggests there are three main factors that affect performance, namely the individual (ability to work), work effort (desire to work), and organizational support (opportunity to work).

[5]Tabrani Rusyan suggests that: The success of teacher performance is supported by several factors: (1) Motivation of performance; (2) Performance ethos; (3) performance environment; (4) Duties and responsibilities and (5) Optimization of performance.

Good teacher performance gives a role to the improvement of the quality of education, but the reality is that there are still many teachers who have poor performance so that the quality of education produced is not good. The phenomenon that occurs in Binjai City Public High School can be seen that there are still teachers who do not compile a syllabus, make lesson plans, and the inability of teachers to describe the curriculum into teaching programs, there are still teachers who are less skilled in teaching, lack of understanding of teaching methods, limitations the source of knowledge that the teacher has in teaching, and there are still teachers who are not disciplined in attendance, always late in going to school to the class even though it has been marked by a bell, there are still teachers who carry out their duties just to give up their teaching responsibilities at school. 
The problem of leadership always gives an interesting impression, because an organization will succeed or fail to be influenced by the quality of leadership. Leadership is the ability to influence, move and direct actions to a person or group of people to achieve certain goals in certain situations. Leadership is one of the managerial aspects of organizational life which is a key position. Because the leadership of a leader acts as a harmonizer in the process of cooperation between humans in their organizations.

Organizations will be strongly influenced by leadership factors, as well as schools that are influenced by the leadership of the principal. [6]Alan Tucker in Syafarudin argues that: "leadership as the ability to influence or encourage someone or a group of people to work voluntarily to achieve certain goals or targets in certain situations."

Working climate also has a role in improving teacher performance in school, as stated by [7]Hoy and Miskel that there is behavior in every organization has a function that is not simple because there are a number of individual needs and organizational goals in want to be achieved together. The relationships between elements in it are very dynamic, they bring unique habits from their homes with all the symbols and motivation.

Motivation is something that needs to be a concern to encourage the creation of good teacher performance. Motivation needs to be maintained and developed so that the teacher has the strength and strong will to develop the potential that exists in him. As stated by [8]Winardi that motivation is an important determinant of individual performance. Furthermore [9] Siswanto said that a person's motivation will be determined by the stimulus which is the engine of a person's motivation so that it influences the behavior of the person concerned. Motivation of the work of the teacher who is well built will have an impact on the teacher's performance. Good work motivation will also provide opportunities as well as challenges for teachers to develop themselves and conduct various new innovations to deal with various problems faced in carrying out their duties and responsibilities in teaching.

Based on the analysis above, there are several factors that influence teacher performance including, the principal's leadership factors, work climate factors and work motivation factors. The extent to which these factors can affect teacher performance can be identified through scientific studies entitled "The influence of Head master leadership, Work climate and Work motivation toward the Teachers Performance at SMA Negeri Binjai."

The purpose of this study was to find out:

1. The influence of the principal's leadership on work motivation at SMA Negeri Binjai

2. The influence of work climate on work motivation at SMA Negeri Binjai

3. The influence of the principal's leadership on teacher performance at SMA Negeri Binjai

4. The influence of work climate on teacher performance at SMA Negeri Binjai

5. The influence of work motivation on teacher performance at SMA Negeri Binjai
Performance comes from English, namely performance. According to the Institute of State Administration (LAN) Smith in [10]Mulyasa (2005: 136) describes the performance to be defined as performance which means work performance, work performance, work achievement or work results.

Veitzhal Rivai in [11]Mulyasa suggests aspects of performance appraisal among others: (1) Technical ability, namely the ability to use knowledge, methods, techniques and equipment used to carry out the tasks and experience and training gained; (2) Conceptual ability, namely the ability to understand the complexity of the company and adjust the field of motion of each unit into the overall operational field of the company, which essentially understands the duties, functions and responsibilities as an employee; (3)

The ability of interpersonal relationships, namely the ability to work with others.

Leadership is the most important thing in an organization, and the progress and withdrawal of an organization is largely determined by leadership, if both the leadership process is running then it will give the opportunity for advanced organizations and make various accelerations to get to the goals of the organization, but otherwise leadership that is not good will have an impact bad for the organization, and can even lead to the dissolution of the organization itself.

According to [12]Ivanchevich leadership is an attempt to use this type of influence not enforcement to motivate people to achieve certain goals.

These various definitions indicate that leadership involves the influence and importance of the communication process. In addition, other elements in the definition are focused on achieving goals. The effectiveness of leaders is especially seen with a measure of the level of achievement of one or a combination of these goals.

Thomp in [13]Syafaruddin explains that the principal is a very important person in the school system. They seek, maintain rules and discipline, provide necessary items, carry out and improve school programs, and choose and develop employees.

The principal also has a function as manager who is responsible for coordinating all available resources to achieve the stated goals by providing direction, guidance and guidance for the implementation of their respective tasks.

Climate translation work from English working climate or working environment. [14]Keith Davis suggests that the work climate is an environment and infrastructure, human beings in which members of the organization do their work.

[15]Litwin and Stringer in Hoy and Miskel the work climate is a set of measurable properties of the work environment, based on the collective perception of the people who live and work in the environment and are proven to influence their behavior. This means that a conducive school work climate will have an impact on teacher performance.

The motivation comes from the Latin word "movere" which means encouragement or movement. [16]Hasibuan argues that motivation is a matter of how to direct power and the potential to work towards the stated goals. 
[17]Stokes defines work motivation as a driver for someone to do his job better, is also a factor that makes the difference between success and failure in many ways, and is a very important emotional force of new work. The research paradigm can be seen in Figure 2.1 as follows:

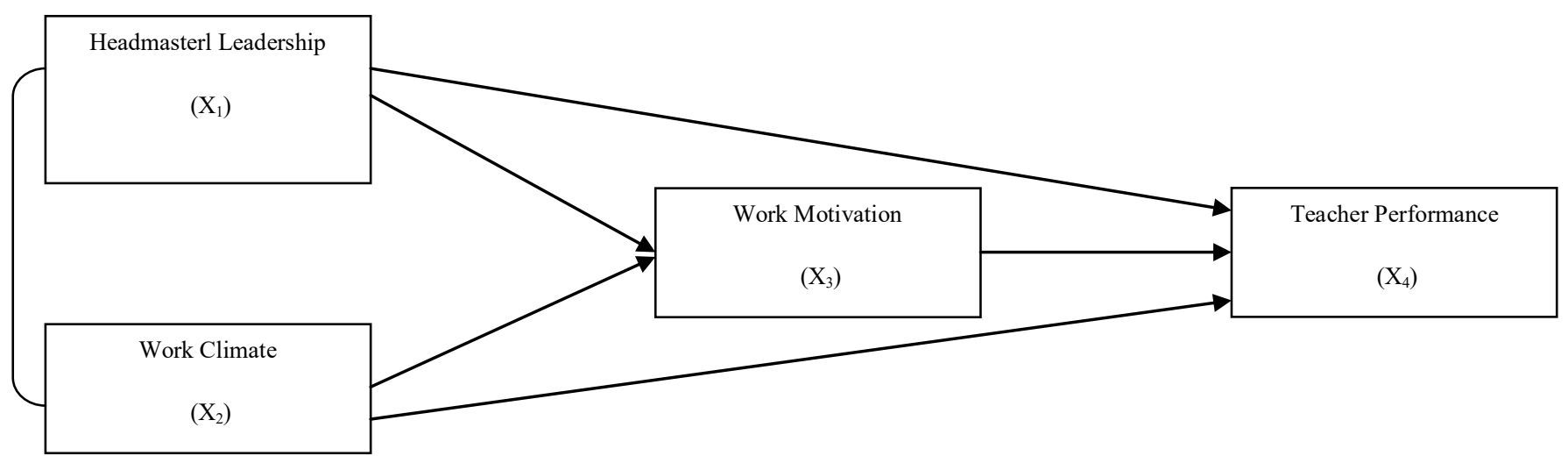

Fig 1 Research Paradigma

Note :

$\mathrm{X}_{1}=$ Headmaster Leadership

$\mathrm{X}_{2}=$ Work Climate

$\mathrm{X}_{3}=$ Work Motivation

$\mathrm{X}_{4}=$ Teacher Performance

\section{Research Hypothesis}

Based on the theoretical framework and thinking framework, the research hypothesis is formulated as follows:

1. The Headmaster leadership has a direct positive effect on the Teacher's Work Motivation at SMA Negeri Binjai

2. Work Climate has a direct positive effect on Teacher's Work Motivation at SMA Negeri Binjai

3. Headmaster leadership has a direct positive effect on teacher performance at SMA Negeri Binjai

4. Work Climate has a direct positive effect on Teacher Performance at SMA Negeri Binjai

5. Work Motivation has a direct positive effect on Teacher Performance at SMA Negeri Binjai

The location of the study was conducted at SMA Negeri Binjai. The study was conducted from October 2017 to February 2018.

This research is a quantitative research with the design of expost facto research namely the variables studied are revealed according to the facts based on the measurement of the symptoms that have been owned or test what will happen.

The population in this study were all public high school teachers at SMA Negeri Binjai, amounting to 501 teachers, the number of samples was 0.33 X 501 X $1.195=197,569=198$ teachers.

This study uses a data collection instrument in the form of a questionnaire. The questionnaire was prepared and designed in such a way and used to measure teacher performance, principal leadership, work climate and work motivation.
Data is collected using a questionnaire with 5 option options aimed at avoiding doubtful answers. The questionnaire through the instrument was used to capture data on the principal's leadership variables, work climate, work motivation and teacher's work variables.

For questionnaires statements and alternative answers include 5 options: Always (SL), Frequent (SR), Sometimes (KK), Rarely (JR), and Never (TP). The answers to each positive statement are given a score: Always $=5$, Often $=4$, Sometimes $=3$, Rarely $=2$, Never $=1$. While for the answers to negative questions each is given a score: Always $=1$, Often $=2$, Sometimes $=3$, Rarely $=4$, Never $=5$

\section{Trial Instrument Testing}

Before the instrument was used for research, the instrument was first tested to get a valid and reliable data collection tool and to know the teacher's understanding of the statement items. Instrument trials were conducted on 30 teachers of SMA Negeri Binjai who did not include a population sample.

\section{Validity Test (validity)}

To find out the accuracy of the instrument, test the validity of the item by using the product moment correlation formula as described by [18]Arikunto with the following formula:

$$
r_{x y}=\frac{n \cdot \sum x y-\left(\sum X\right)\left(\sum Y\right)}{\sqrt{\left.\left\{n \cdot \sum X^{2}-\left(\sum X\right)^{2}\right\} n \cdot \sum Y^{2}-\left(\sum Y\right)^{2}\right\}}}
$$

Based on the results of the research instrument trial of 30 (thirty) respondents, namely teachers at SMA Negeri Binjai and after calculating the validity of instrument items, the following valid instrument items will be obtained:

a. For the Principal Leadership variable instrument (X1) of 32 (thirty two) questions tested, there are 2 invalid items so that the instrument used to capture data is 30 items. 
b. For the instrument of Working Climate variable (X2) of 32 (Thirty two) questions tested, there are 2 items that are invalid (fall) so that the instrument used to capture data is 30 items.

c. For the instrument of Work Motivation variable (X3) of 32 (thirty two) items tested, there are 4 items that are invalid (fall) so that the instrument used to capture data is 28 items.

d. For the instrument variable Teacher Performance (X4) out of 32 (thirty two) items tested, there are 3 items that are invalid (fall) so that the instrument used to capture data is 29 items.

Test Reliability (reliability)

Questionnaire reliability will be tested using the Alpha Cronbach technique as follows:

$$
r^{11}=\frac{n}{n-1}\left[1-\frac{\sum \sigma^{2}}{\sigma_{t^{2}}}\right]
$$

\section{Calculation of Path Analysis}

In testing the research hypothesis, path analysis uses a significance level of $\alpha$ of 0.05 . In connection with using path analysis, [19]Al-Rasjid suggests that when conducting an analysis, it must first be described in a diagrammatic way the structure of direct and indirect influences between endogenous and exogenous variables. Based on the theoretical model developed, the research path diagram can be described as follows:

\section{RESEARCH RESULT DISCUSSION}

In accordance with the theoretical model developed in this study, there are 5 hypotheses tested by Path Analysis. Based on the results of the test obtained a path diagram that describes the structure of the causal relationship between exogenous variables with endogenous variables as in Figure 4.6 below:

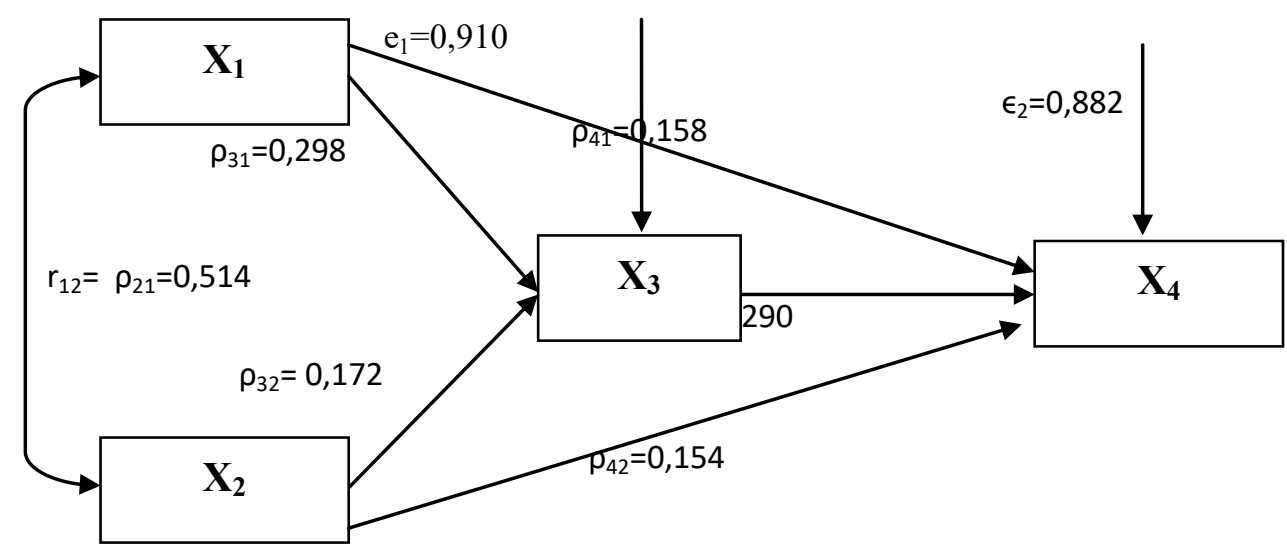

Fig 2. Pathway Variable of Research Variables Hypothesis Testing Results

Note :

$\mathrm{X}_{1}=$ Headmaster Leadership

$\mathrm{X}_{2}=$ Work Climate

$\mathrm{X}_{3}=$ Work Motivation

$\mathrm{X}_{4}=$ Teacher Performance

$\mathrm{e}_{1}, \mathrm{e}_{2}$ : Residu Varible

In connection with the path diagram the research findings are carried out as follows:

1. The increasing leadership capacity of the principal will be able to improve the work motivation of teachers better.

2. The more conducive work climate is created, it will be able to improve the work motivation of teachers better.

3. The better the leadership of the principal, will be able to improve teacher performance.

4. Increasingly a good work climate, will be able to improve work motivation better so that the teacher's performance is better.

5. The increasing motivation of the teacher's work, will be able to improve teacher performance.

\section{CONCLUSION}

Based on the results of statistical calculations and the results of the data analysis described above, the following conclusions can be drawn:

1. Principal leadership has a direct positive effect on work motivation. This shows that the better the headmaster's leadership, the higher the teacher's work motivation at SMA Negeri Binjai.

2. Work climate has a direct positive effect on work motivation. This shows that the better the work climate is built, the higher the work motivation of teachers at SMA Negeri Binjai

3. Principal leadership has a direct positive effect on teacher performance. This shows that the better the level of leadership of the principal of the teacher, the higher the performance of teachers at SMA Negeri Binjai. 
4. Work climate has a direct positive effect on teacher performance. This shows that the higher the work climate is built, the higher the performance of teachers at SMA Negeri Binjai.

5. Work motivation has a direct positive effect on teacher performance. This shows that the higher the teacher's work motivation, the higher the teacher's performance at SMA Negeri Binjai.

\section{REFERENCES}

[1] Ace Suryadi dan H.A.R. Tilaar. 1994. Analisis Kebijakan Pendidikan Suatu Pengantar. Bandung: Remaja Rosdakarya.

[2] Mulyasa, E. 2007. Menjadi Guru Profesional. Bandung: Remaja Rosda karya.

[3] Dale, Timpe A. 2000. Seri Manajemen Sumber Daya Manusia, Kepemimpinan. Jakarta: Gramedia

[4] Sutiadi, 2003, Motivasi Karyawan Dan Aktifitas Manajerial Kepemimpinan Terhadap Kinerja Karyawan. Pasca Sarjana, Universitas Brawijaya, Malang.

[5] Tabrani dkk. 1989. Pendekatan dalam proses belajar mengajar. Bandung; Remadja Karya

[6] Syafaruddin. 2005. Manajemen Lembaga Pendidikan Islam. Jakarta: Ciputat Press.

[7] Hoy, Wayne K. \& Miskel, Cecil G. 2001. Education Administration: Theory, Research, and Practice $\left(6^{\text {th }} \mathrm{ed}\right.$., international edition). Singapure: Mc Graw-Hill Co.
[8] Winadi, J. 2007. Motivasi dan Pemotivasian dalam Manajemen. Jakarta: Raja Grafindo Persada.

[9] Siswanto. 2007. Pengantar Manajemen. Jakarta: Bumi Aksara

[10] loc.it

[11] Mulyasa, E. 2007. Menjadi Guru Profesional. Bandung: Remaja Rosda karya.

[12] Ivanchevich, John. M. Donely Jr., James H; James L. Gibson, 1995. Organisasi jilid I. Jakarta: Erlangga

[13] Syafaruddin. 2005. Manajemen Lembaga Pendidikan Islam. Jakarta: Ciputat Press.

[14] Davis, Keith, 1972, Human Behavior at Work : Human Relations and Organizational Behavior, Fourth Edition, McGraw-Hill, New York.

[15] Hoy, Wayne K \& Cecil G. Miskel. (2008) Education Administration : Theory, Research, and. Practice

[16] Hasibuan. M.S.P. 2006. Manajemen Sumber Daya Manusia. Jakarta: Bumi Aksara.

[17] Stokes, T. F., Osnes, P. G., \& Guevremont, D. C. (1987). Saying and doing: A commentary on a contingency-space analysis. Journal of Applied Behavior Analysis, 20, 161164.

[18] Arikunto, Suharsimi. 1988. Prosedur Penelitian : Suatu Pendekatan Praktek. Jakarta: Rineka Cipta.

[19] Al-Rasyid, Harun. 1994. Teknik Penarikan Sampel dan Penyusunan Skala. Bandung: Universitas 